\title{
Design Optimization of Real Estate Tax and Effect Analysis in China
}

\author{
Jingjuan Guo, Aibo Hao, Yipeng Ren \\ School of Economics and Management, Beijing Jiaotong University (China) \\ guojingjuan@sina.com,bjtu120687@163.com,12120692@bjtu.edu.cn
}

\section{Abstract:}

Purpose: The objective of this research is to reform the current real estate tax system and establish the real estate tax system suitable for China's national conditions.

Design/methodology: Based on the necessity of the real estate tax reform, the paper studies the system optimization and its effects analysis of the real estate tax. At last, the paper uses the system dynamics to demonstrate the feasibility of the real estate tax from an empirical point.

Findings: With the system dynamics, we can establish the causal relationship of the influence factors and forecast the impact on the future real estate prices. It can also provide some suggestions for China's real estate tax reform.

Research limitations/implications: The establishment of the model might not be very mature, so we need the further study and improvement.

Originality/value: This study was the first to use system dynamics to analyze the impact of real estate taxes on real estate prices, and we hope to provide some suggestions for China's real estate tax reform.

Keywords: real estate tax, design optimization, effect analysis, system dynamics 


\section{Introduction}

In recent years, with the rapid development of the real estate industry in China, there are still many problems and shortages in the real estate tax system. To Regulate the real estate market and control the effect of widening income gap through the real estate tax is difficult to reflect, so it is very important for the healthy development of China's real estate market and our tax system to reform the current real estate tax system and establish a complete set of the real estate tax system. Based on the necessity of the reform of the real estate tax, we learn from the successful experience in the real estate tax of foreign country in order to establish a feasible and effective real estate tax system in the light of the actual situation of China. Meanwhile we analyze the economic effects brought by the real estate tax optimization from both theoretical and empirical aspects.

\section{Domestic and Foreign Real Estate Tax System}

\subsection{Present Situation of Real Estate Tax System in China}

The basic framework of China's current real estate tax system is formed after the comprehensive structural tax reform in 1994. With the deepening of reform and opening up, China's economic situation has undergone great changes, so some taxes has been unable to meet the economic development and social life and exposed a number of drawbacks, and even had a negative impact on the stability and development of the economy.

- Base of the tax is narrow.

The base of China's real estate property tax and urban real estate tax haven't cover to the personal non-operating real estate so far (Wang, 2008). And the long-term neglect of taxation during the individual housing occupies phase can not only cause huge losses to the state's tax revenue, but also be conducive to smooth and orderly development of the real estate and the country's macro-control.

- The taxes are Complicated.

The same tax base, the similar nature of the taxes imposed repeatedly in different stages of taxation, such as land value increment tax and income tax exists the phenomenon of repeated taxation (Zhang, Yan \& Song, 2012).

- The heavy tax burden in the circulation phase and light tax burden in holding phase.

The most taxes in China's real estate industry is focused on the development and the trading phase, mainly including tax on occupation of cultivated land, business tax, urban maintenance and construction tax, stamp tax, deed tax, land value increment tax 
and income tax, while the taxes in the holding phase only include property tax and urban land use tax, leading to the tax burden is very low (Qiu, 2009).

- The local government's fiscal balance is difficult to maintain.

Since the tax reform in 1994, the central government received a large number of property rights, especially $75 \%$ of the land appreciation tax had been owned by the central government, and income tax in local taxes had also been shared by both the central and local governments after 2002. At the same time with the property rights of the local government to hand in, fiscal expenditure responsibilities had also increased, such as local governments not only need to take a constructive expenditure, nonwelfare expenditure and administrative expenditure, but also need to assume a variety of social security expenditure, price subsidies and so on (Wang \& Sun, 2012). Under the system of property rights handing in and responsibilities increasing, the local government's fiscal balance is difficult to maintain.

\subsection{Foreign Experiences of Real Estate Tax System}

The real estate market of western developed countries is relatively stable, the United States as the representative of developed countries and regions has a long history of the real estate tax and its tax system is designed more perfectly. Hong Kong and the mainland China uses the same land leasing system-he government manage the land and lease to the land developers or users- can provide a reference for China's real estate tax system optimization (Qiu, 2009; Wang, 2008; Wang \& Sun, 2012).

- The principle of the taxation is to widen the base, distinguish the taxes, divide into categories and reduce tax rate.

The real estate tax base covers a wide range, such as Hong Kong property levy rates, there is very few properties to be exemption, so it is difficult for tax avoidance or tax evasion; The real estate is taxed at different rates according to the different uses of the real estate. For example, the United States has different tax rates for different uses such as residential, commercial, industrial estate (Zhang et al., 2012); Taking into account the affordability of the people, the real estate tax rates are generally not high. For example, the average tax rate of the United states is $1 \%-3 \%$, the rate of Hong Kong in recent years is about $5 \%$. 
- The real estate tax of the holding phase dominates the real estate tax system.

Compared with the tax administration in the real estate development, trading and other phases, the real estate taxes come mainly from real estate holding phase in the United States and other developed countries.

- The real estate tax of the holding phase dominates the local taxes and fiscal revenue.

The real estate tax of the holding phase constitutes the main part of the local taxes. It not only helps to mobilize the enthusiasm of local governments to levy property taxes, but also helps to expand the scale of investment in local infrastructure and utilities and to form a virtuous cycle of growth in tax revenue.

- The appropriate tax exemption policies.

The most countries have set up some tax exemption policies. At the same time, in order to reflect the social justice and to prevent the distance between the rich and the poor, we can consider to tax the heavy taxes to the landowners and the rich.

- Supporting measures are perfect, laws and regulations are complete.

First, States have a special evaluation agency property valuation. The "Real Estate Valuation Office" in Britain, summary annual real estate transaction information and format an independent real estate appraisal systems, to announce different types, different uses of land or real estate prices in regional cities of the UK. Second, these specialized rating agencies have set up detailed information reserves. In order to strengthen the local property tax levy, the United States government establish a more detailed property information management system. Data cards are the most common management methods among these. The information on the card is very comprehensive, including location, heading, property types, change of ownership situation, the composition and valuation changes, the type of construction, type of land, housing type and quantity and so on.

In view of the drawbacks of the current real estate system, it is imperative to optimize and integrate. The mature real estate taxes of other foreign countries or regions are also very helpful for us. Based on this, we propose the optimization of China's real estate tax system and analysis its effect on China's real estate market. 


\section{The Design Optimization of Real Estate Tax in China}

In order to solve the problems proposed above, the real estate tax system optimization should focus on the holding phase, it means to levy the real estate tax in the holding phase-to merge the property tax, urban land use tax of the holding phase and the land leasing into the real estate tax, and cancel the land value increment tax (Qiu, 2009; Wang, 2008; Xu, 2007).

\subsection{The beneficial effects of incorporating the land leasing into the real estate tax}

- It helps to regulate the local government land leasing behaviors and promote the sustainability of the land leasing. The distribution of land leasing to the real estate tax year after year can completely change the local government short-term grant money mode and promote the sustainable land transferring.

- It helps to reduce the real estate development costs and reduce real estate prices. Incorporating the land leasing into the real estate tax can transfer the land premium burden from the real estate developers to property owners and effectively reduce the barriers to market entry.

- It helps to equitable distribute the benefits of the appreciation of the land. Incorporating the land leasing into the real estate tax and charging at a certain percentage of the value of real estate can get a more equitable distribution of income between the property owners and the government.

\subsection{The irrationality of China's land value increment tax in theory and practice}

Firstly, the land value increment tax and income tax exists the phenomenon of repeated taxation; Secondly, the land value increment tax in China use the higher progressive rates which is opposite to the international practice. In practice, because of the complex taxation and higher tax rates, there are many difficulties and problems in the expropriation process. From these angles, we can cancel the land value increment tax and take other marketoriented, more effective means on the purpose of curbing the real estate speculation.

\subsection{Scope of real estate tax}

The real estate tax should broaden the tax base on the basis of the scope of the current real estate tax, including the land that are used or sold in city, county, towns and industrial and mining areas and all business and residents-occupied real estate. 


\subsection{Object of real estate tax}

China's land system is public ownership, that is different from the privatization of land in developed countries, so the land is not a real sense of private property. We can consider to separate the land and the houses to levy taxes. For the land, we distribute land leasing to the real estate tax and levy taxes every year; for the houses, we base on the value of the real estate assessments.

\subsection{Real estate tax rate}

As China's real estate tax optimization is at the exploratory stage, the real estate tax is more appropriate to adopt a fixed proportional tax rate in the early stage to pursuit the best combination of efficiency and fairness as far as possible.

The scope of the real estate rate can be unified set by the central, and give local government some freedom to choice the tax rate applied to their own areas.

China's real estate tax should not only guarantee local government revenue, but also not leave the tax burden of the residents is too high. It means the real estate tax revenue should not be less than the sum of the current tax revenue that be merged into the real estate tax; Meanwhile, to avoid taxpayers to bear too heavy tax burden on the measure basis of the ratio of the tax revenue to the social total output (Liu, 2012).

$$
\frac{T R}{T V_{R}-T E+T V_{N \pi}} \leq r \leq \frac{C \times G D P}{T V_{R}-T E+T V_{N R}}
$$

$r$ - the real estate tax rate;

TR - the sum of the property tax, urban real estate tax and urban land use tax;

TVR - the total value of residential real estate;

TVNR - the total value of non-residential real estate;

TE - the total exemption amount of residential real estate;

C - the upper limit of the real estate macro tax burden;

GDP - Gross Domestic Product. 


\section{Analysis of the Economic Effects of Real Estate Tax on Real Estate Prices}

\subsection{Theoretical analysis of the impact of Real Estate taxes on real estate prices}

China's real estate tax reform is a systematic project, that is directly related to the interests of all parties in the real estate industry and involves all phases of land and property acquisition, development, trading and holding. So it is inevitable to affect the real estate prices ultimately by affecting the participating subjects' behaviors of the real estate market (Mutingi, 2013).

\subsubsection{The local government}

Theoretically the real estate tax of the holding phase is the most suitable type of taxes as a major source of local government revenue. Because of incorporating the residential into the tax, the base of the tax greatly increases; With the economic development and urbanization, the tax revenue is always a long-term growth trend; Meanwhile, based on non-current of the real estate, the real estate tax is also very stable. From the three aspects above, the real estate tax will inevitably become an important source of local government finance to achieve the goal of increasing local fiscal revenue.

Meanwhile, the optimized tax system can balance the government's long-term revenue, no matter what term the government granted land use rights, each installment payment of taxes will have a steady income for the government. To tax in accordance with the real estate market prices makes the revenue directly linked with land and house values, prompt the local government to change its short-term behavior, to focus more on the development of the real economy. From the long-term interests to consider the investment environment of the real estate market, It can also improve the local hard environment and soft environment to ensure sustainable development of the city.

\subsubsection{The real estate developers}

With the optimization of the real estate tax, the taxes paying by developers originally paid by the owners every year, so it effectively reduce the barriers to market entry and reduce its over-reliance on bank lending in order to reduce the risk of investment in the real estate industry. In addition, the increase of cost of ownership will inhibit consumption and speculative demand, so developers will be adjusted the supply structure according to the needs in order to improve use efficiency and promote efficient allocation of resources. 


\subsubsection{Customers}

Emphasis on the real estate tax of the holding phase can reduce the down payment, release the potential demand in the real estate market, reduce the interest payments on loans and to realize the dream of low-and middle-income family housing. At the same time, it is able to guide rational consumption and effectively curb speculative investment to form a reasonable pattern of resource allocation, which will help residents to purchase the suitable size for living.

The real estate tax will have an impact on the real estate price by acting on the participating body of the real estate market, thus the relationship among them can be seen in the following figure:

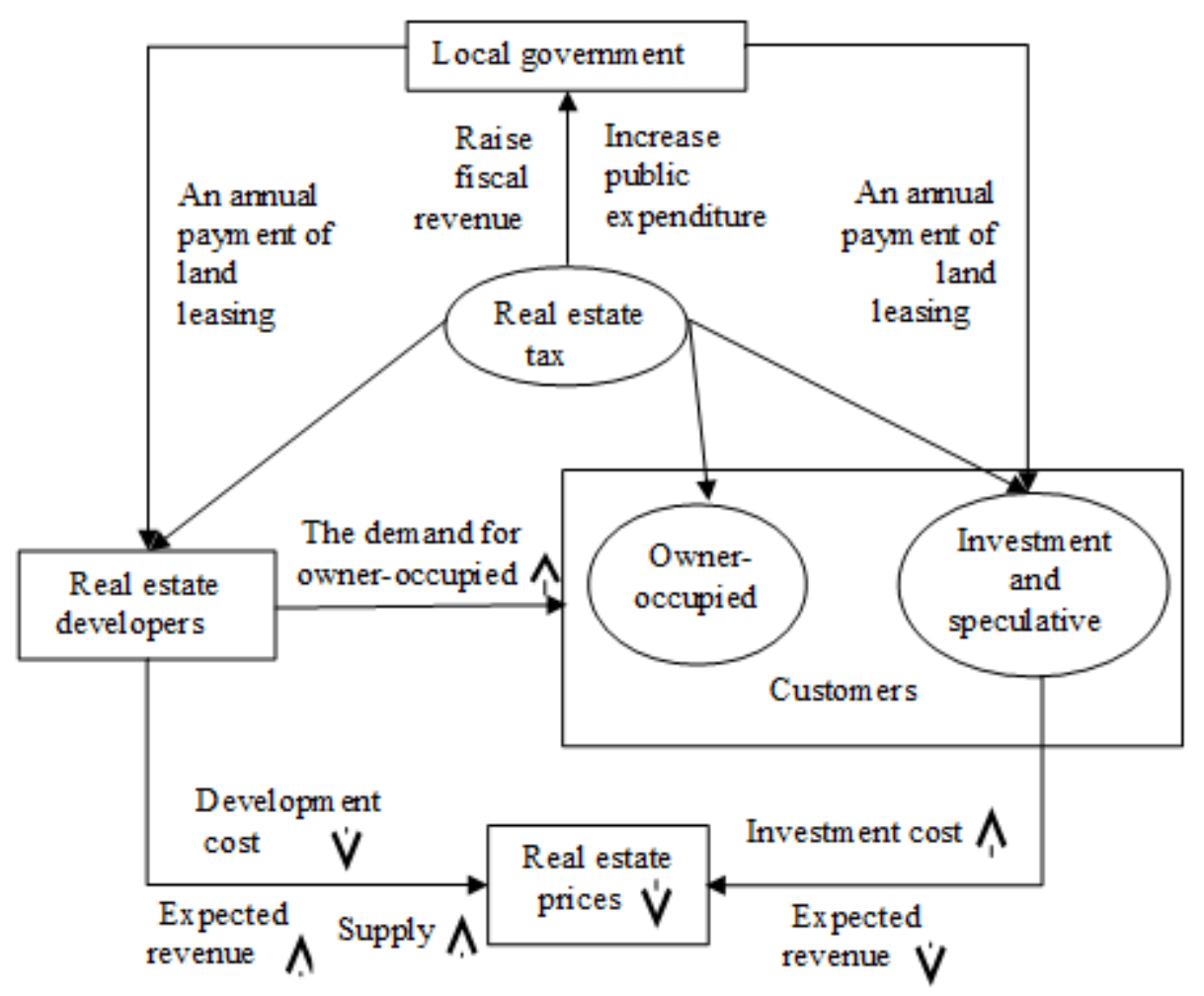

Figure 1 . The impact of the real estate tax on the real estate prices

\subsection{Analysis of the impact of Real Estate taxes on real estate prices based on the system dynamics model}

The introduction of real estate tax would theoretically have a certain impact on the real estate prices, however, there are a large number of influencing factors to the prices and the relationship of them are very complex. So we need to quantify the impact of tax changes on prices. With the system dynamics software-Vensim PLE to establish the causal relationship of the influence factors, we use the historical data of 2001-2012 to operate the system simulation and model test, meanwhile forecast the impact on the future price (Yin, Xie \& Guo, 2012). 


\subsubsection{Causal loop diagram}

Causal loop diagram indicates the relationship of promote or constrain among the various factors with the arrow, the + indicates a positive relationship, the - indicates a negative relationship (Ji, 2008). The causal relationship of the impact on real estate prices is shown below:

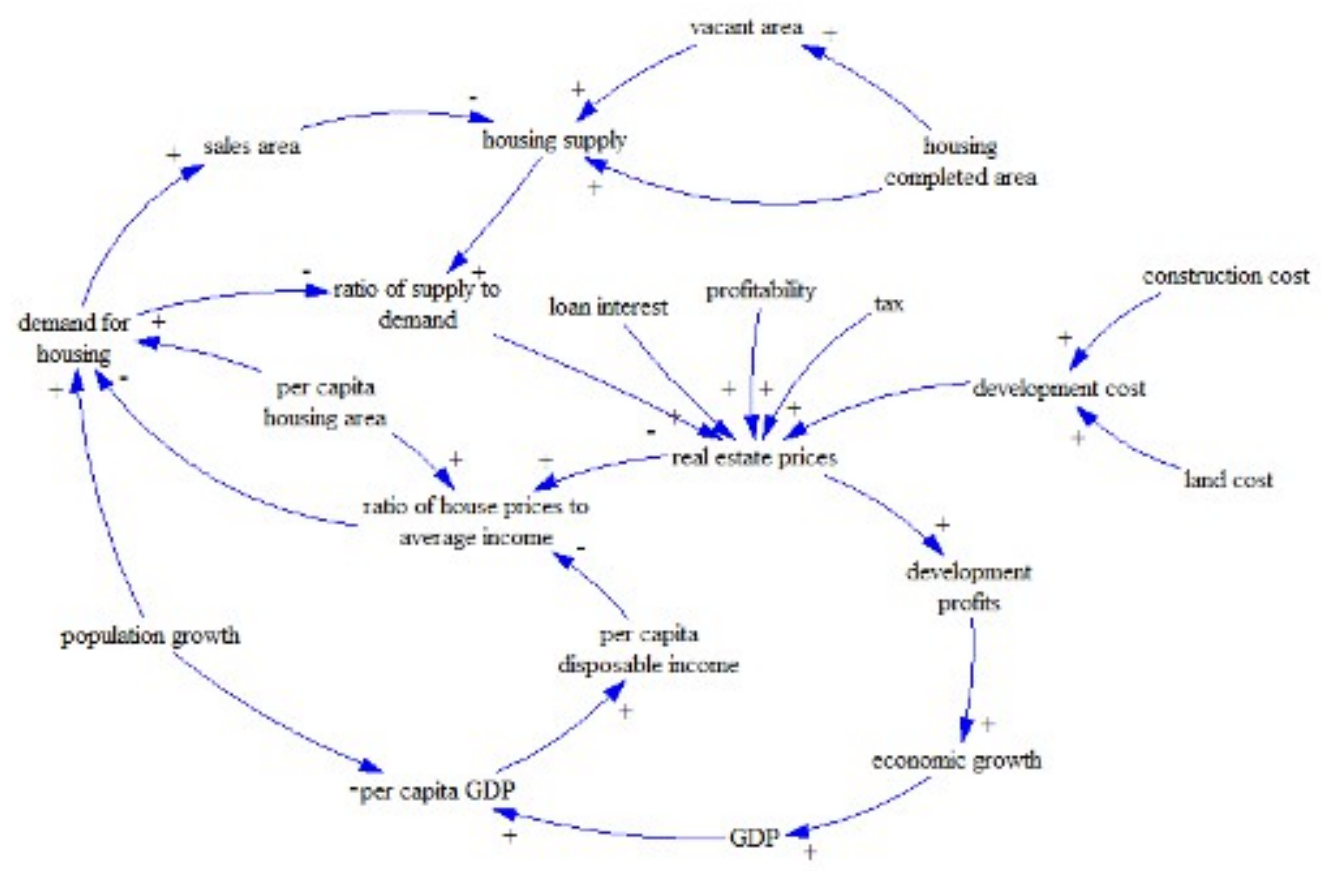

Figure 2. Causal loop diagram of the impact on the real estate prices

\subsubsection{System flow diagram}

To ensure the correctness and operability of the model and the collection range of the data, we will simplify the causal loop diagrams. It means to select the main factors, such as the real estate prices, population, ratio of house prices to average income, ratio of supply to demand, to establish the system dynamics flow diagram as follows: 


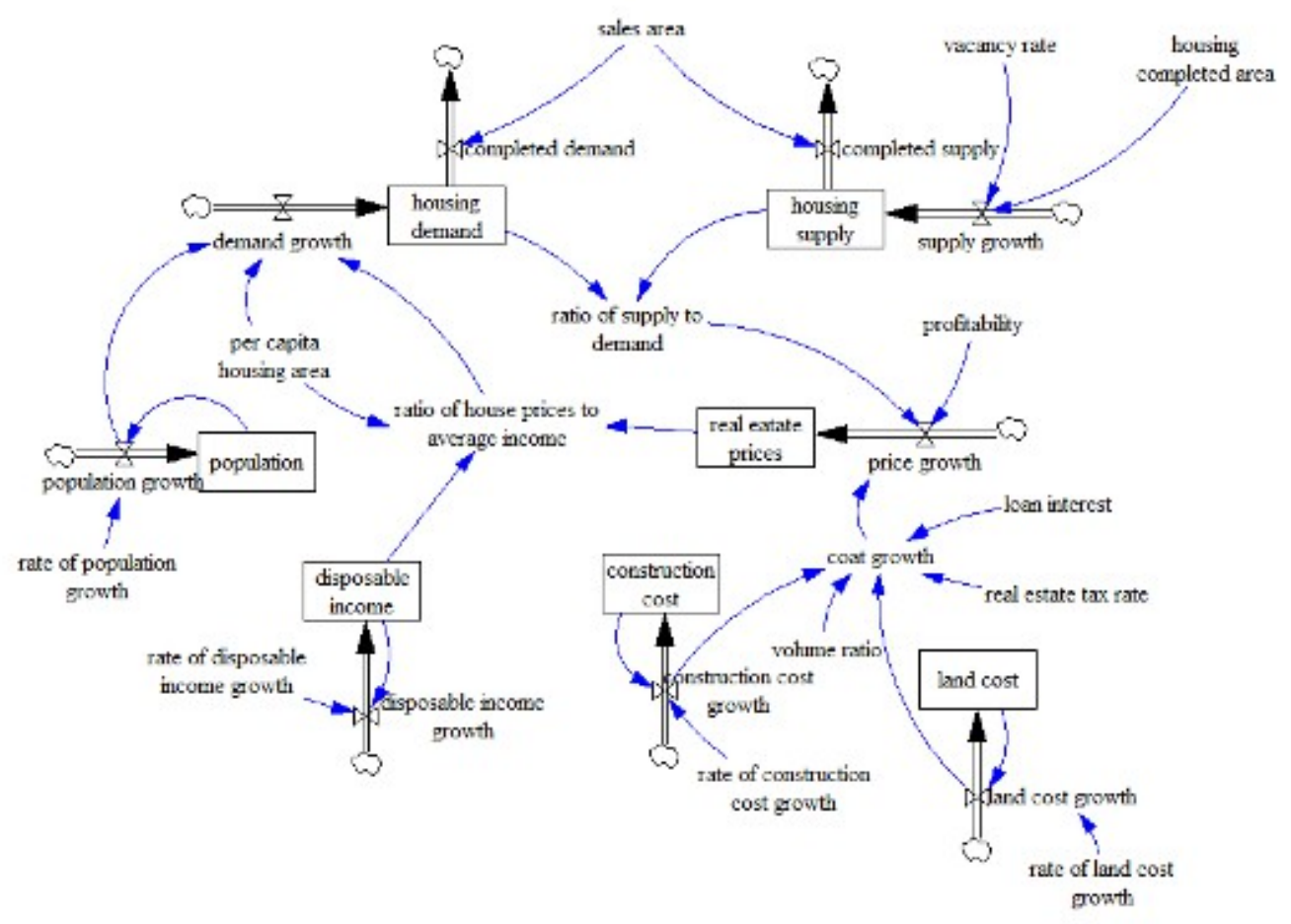

Figure 3. System flow diagram of the impact on the real estate prices

\subsubsection{Model equations}

With the data of the model from the China Statistical Yearbook and related statistics, we analyze the relationship of the various variables and establish the corresponding model equation (Lin \& Liu, 2009). The main equations of the model include:

The real estate prices $=$ INTEG (price growth, 2170)

As the initial value of the real estate prices, 2170 yuan per square meters is the average selling price of national real estate in 2001; INTEG ( ) is the cumulative sum function of the Vensim PLE.

Price growth $=$ cost growth* $(1+$ profitability $) *$ ratio of supply to demand

The profitability is $20 \%$.

Cost growth $=($ land cost growth/volume ratio + construction cost growth/0.65 $) *(1+3 *$ loan interest/100 $) *(1+$ tax rate $)$ 
According to the relevant research data, the volume rate is 1.5 , the construction cost accounts for about $65 \%$ of development cost, loan interest is $1-3$ years lending rates of the commercial bank. With the tax collection methods and experiences in the real estate development phase, business tax and land value increment tax accounted for $5 \%$ and $3 \%$ of sales, urban maintenance and construction tax and education surcharge account for $7 \%$ and $1 \%$ of business tax, overall the tax account for $6.5 \%$ of the sales. We regard taxes as a part of the real estate prices when we calculate the tax rate, and the ratio of it to the rest part of the real estate prices is $6.5 \%$, so the tax rate in this model is designated as $7 \%$.

$$
\text { Supply growth=housing complete area*(1+vacancy rate) }
$$

The vacancy is $14.5 \%$.

$$
\begin{gathered}
\text { Demand growth=ratio of housing prices to average income*per capita } \\
\text { housing area*population growth }
\end{gathered}
$$

Housing supply=INTEG(supply growth-completed supply,25104.9)

The housing completed area of 2000 is 251049 thousand square meters, so we set the initial value of the total supply of 2001 at 251049 thousand square meters in the simulation process.

Housing demand=INTEG(demand growth-completed demand, 31061.8)

The housing sales area of 2000 is 186371 thousands square meters, and we assume that the actual housing demand of about $60 \%$ of the residents are satisfied, so we set the initial value of the total demand of 2001 at 310618 thousand square meters.

$$
\begin{gathered}
\text { Ratio of housing prices to average income=per capita housing area*real } \\
\text { estate prices/per capita disposable income } \\
\text { Ratio of supply to demand=housing supply/housing demand } \\
\text { Construction cost=INTEG(construction cost growth,1128) }
\end{gathered}
$$

The housing completed cost of 2001 is 1128 yuan per square meters. 
The land transaction price of 2011 is 1038.8 yuan per square meters.

$$
\text { Population=INTEG(population growth,127627) }
$$

The national population of 2001 is 1276270 thousands.

$$
\begin{gathered}
\text { Construction cost growth }=\text { construction cost*rate of construction cost } \\
\text { growth } \\
\text { Land cost growth=land cost*rate of land cost growth } \\
\text { Population growth }=\text { population*rate of population growth }
\end{gathered}
$$

\subsubsection{Simulation results and model test}

Based on the causal loop diagrams and flow diagrams and the variables values of the system dynamics model, we simulate the national real estate prices from 2001 to 2012 with the Vensim PLE software and the simulation results are shown as follows:

\begin{tabular}{|l|l|l|l|l|l|l|l|l|l|l|l|l|}
\cline { 2 - 13 } \multicolumn{1}{c|}{} & $\mathbf{2 0 0 1}$ & $\mathbf{2 0 0 2}$ & $\mathbf{2 0 0 3}$ & $\mathbf{2 0 0 4}$ & $\mathbf{2 0 0 5}$ & $\mathbf{2 0 0 6}$ & $\mathbf{2 0 0 7}$ & $\mathbf{2 0 0 8}$ & $\mathbf{2 0 0 9}$ & $\mathbf{2 0 1 0}$ & $\mathbf{2 0 1 1}$ & $\mathbf{2 0 1 2}$ \\
\hline Actual values & 2170 & 2250 & 2359 & 2778 & 3168 & 3367 & 3864 & 3800 & 4681 & 5032 & 5357 & 5791 \\
\hline Simulation values & 2170 & 2305 & 2492 & 2797 & 3148 & 3300 & 3662 & 3742 & 4479 & 4981 & 5434 & 5824 \\
\hline Relative error(\%) & 0 & -2.45 & -5.66 & -0.67 & 0.64 & 1.98 & 5.23 & 1.54 & 4.32 & 1.02 & -1.44 & -0.6 \\
\hline
\end{tabular}

Table 1. Comparison of actual value and simulation value of national real estate prices

According to the comparison above, we can find that the absolute value of the relative error of the real estate prices of more than $80 \%$ of the year is controlled within $5 \%$, only a few is more than $5 \%$, but it can be controlled within $7 \%(\mathrm{Li}, 2010)$. Therefore, it is possible to think that the system dynamics model is established with a certain degree of authenticity and accuracy.

\subsubsection{Model prediction}

According to the real estate tax optimization proposed above, we will no longer pay the land leasing in the development phase and cancel the land value increment tax that accounts for about $3 \%$ of the sales, so the land cost decrease to zero, meanwhile the real estate tax rate will decline (Hui \& Ho, 2003). Assuming the tax rate reduced to $6.5 \%$, the model simulations of real estate prices of 2001-2015 are shown in the following table. 


\begin{tabular}{|l|l|l|l|l|l|l|l|l|l|l|l|l|l|l|}
\hline Year & 2002 & 2003 & 2004 & 2005 & 2006 & 2007 & 2008 & 2009 & 2010 & 2011 & 2012 & 2013 & 2014 & 2015 \\
\hline $\begin{array}{l}\text { The real } \\
\text { estate } \\
\text { prices }\end{array}$ & 2275 & 2322 & 2377 & 2395 & 2435 & 2466 & 2510 & 2569 & 2641 & 2729 & 2836 & 2966 & 3123 & 3311 \\
\hline
\end{tabular}

Table 2. The prediction results of the real estate prices

Compared to the actual data, it is not difficult to find that the prices are rising at a slow rate, and are lower than the actual data. Therefore, the optimization and the integration of real estate tax can limit the excessive growth of the real estate prices to a certain degree.

\section{Conclusion}

In summary, the design optimization and integration of the real estate tax proposed above, not only effectively solve the problems in the current tax system and avoid double taxation and double standards, but also stabilize the local financial revenue and promote the rational allocation of social wealth. For the local government, it can ensure that the government can get sufficient funds and prompt the government to devote much more energy to economic development; For the real estate developers, it effectively reduce the barriers to market entry and reduce its over-reliance on bank lending in order to adjust its market supply structure, promote the efficient allocation of resources; For consumers, it is able to guide rational consumption and effectively curb speculative investment to ensure healthy and effective operation of the market; For the high prices, we can adjust the relationship between supply and demand to effectively inhibit the excessive growth of it, meanwhile system dynamics model has also proved this point from the empirical aspect.

\section{References}

Hui, E., \& Ho, V. (2003). Does the planning system affect housing prices? Theory and with evidence from Hong Kong. Habitat International, 27(3), 39-59.

Ji, X. (2008). Study on System Dynamics Model Simulation of Commercial Housing Price in Nanjing. Nanjing University of Aeronautics and Astronautics.

Li, J. (2010). Reflection on the Reform of Real Estate in Our Country. Social Scientist, 9, 99-102.

Lin, J., \& Liu, Y. (2009). Study on the impact of the Property Tax on the Real Estate Market. Journal of Chongqing Institute of Technology, 23(4), 4-7. 
Liu, S. (2012). Study on Residents' ability to tax and the reform of the real estate tax. Forward Position, 11, 113-115.

Mutingi, M. (2013). Developing green supply chain management strategies: A taxonomic approach. Journal of Industrial Engineering and Management, 6,(2), 525-546. http://dx.doi.org/10.3926/jiem.475

Qiu, S. (2009). The Study of Imposing Property Tax in China. Shanghai JiaoTong University.

Wang, L., \& Sun, Y. (2012). Review and Theoretical Summary of the Introduction of Real Estate Tax. Fiscal Aspect, 23, 65-67.

Wang, S. (2008). Present Situations and Reform of Chinese Tax System in Real Estate. Shanxi Architecture, China Academic Journal Electronic Publishing House, 34, 247-248.

Xu, J. (2007). Study on System Design and Economic Effects of the Property Tax in China. Fudan University.

Yin, J., Xie, Z., \& Guo, J. (2012). Study on the Real Estate Credit Risk Based on System Dynamics. Journal of System and Management Sciences (2013), 3(1), 31-36.

Zhang, C., Yan, H., \& Song, A. (2012). Research on Influence of Levying Property Tax to Real Estate Tax in China. Shanxi Architecture, China Academic Journal Electronic Publishing House, 38, 255-256.

Journal of Industrial Engineering and Management, 2014 (www.jiem.org)

\section{(ब)}

Article's contents are provided on a Attribution-Non Commercial 3.0 Creative commons license. Readers are allowed to copy, distribute and communicate article's contents, provided the author's and Journal of Industrial Engineering and Management's names are included. It must not be used for commercial purposes. To see the complete license contents, please visit http://creativecommons.org/licenses/by-nc/3.0/. 